Int. J. Speleol. 15 (1986), pp. 15-40

\title{
USE OF CAVE-MAPS FOR TECTONIC SURVEYS
}

\author{
Franz Jaskolla ${ }^{\star}$, Peter Volk ${ }^{\star *}$
}

\begin{abstract}
Results of the author's investigations show the useful application of cave-map-data for tectonic assessment.

Considering speleological features, cave genesis, and structural differences, it is possible to select of the cave map's pattern various jointing and stress systems. By 7 selected cave maps, representing areas of different tectonic history (W-Germay, Austria and Switzerland) it will be demonstrated that three types of kinematic joint-systems can be identified (fundamental, orthogonal- fold- and shear-system).

Therefore, tectonic models are expected to become more valuable. It must be stated that future tectonic investigations in karst-areas should include the additional use of cave maps.
\end{abstract}

\section{INTRODUCTION}

Basing on extensive activities of private people and organisations, a broad and detailed knowledge on the course and construction of numerous caves throughout different karstic regions is existent.

Although very important basic information are collected, often the naturale sciences neglect them as something like "hobbyscience" - a fact, which is proven by literature, specially in geology.

Nevertheless, detailed surveys of caves and numerous descriptions on the situation of passages can be applied advantageous as an additional information source (BAYER, 1985).

* Dr. Franz Jaskolla, Arbeitsgruppe Photogeologie und Fernerkundung am Institut für Allgemeine und Angewandte Geologie, Luisenstr. 37, D-8000 München 2.

* * Dr. Peter Volk, Gesellschaft für Angewandte Fernerkundung - GAF -, Leonrodstr. 69, D-8000 München 19. 
With this presentation, we want to demonstrate the relationship of mapped passage traces and tectonic elements and the impact specially on microtectonics. Starting point is an investigation of VOLK (1982) which outlines the improvement for microtectonic models considering measurements of joints in cave systems.

\section{FUNDAMENTALS}

\subsection{THE DEVELOPMENT OF ENDOKARST (BÖGLI, 1978)}

Karstphenomena are an essential and unique characteristic of all carbonate rocks. Fundamentally, the genesis of caves within endokarst is depending on the intensive solubility of carbonate in presence of acidulated water and an extensive jointing (TRIMMEL, 1968).

\subsubsection{PHREATIC STAGE}

Corrosion is the most active process under phreatic conditions (rock formation is beneath the karst water table) if vugs or capillary active planes are existent (BÖGLI, 1978).

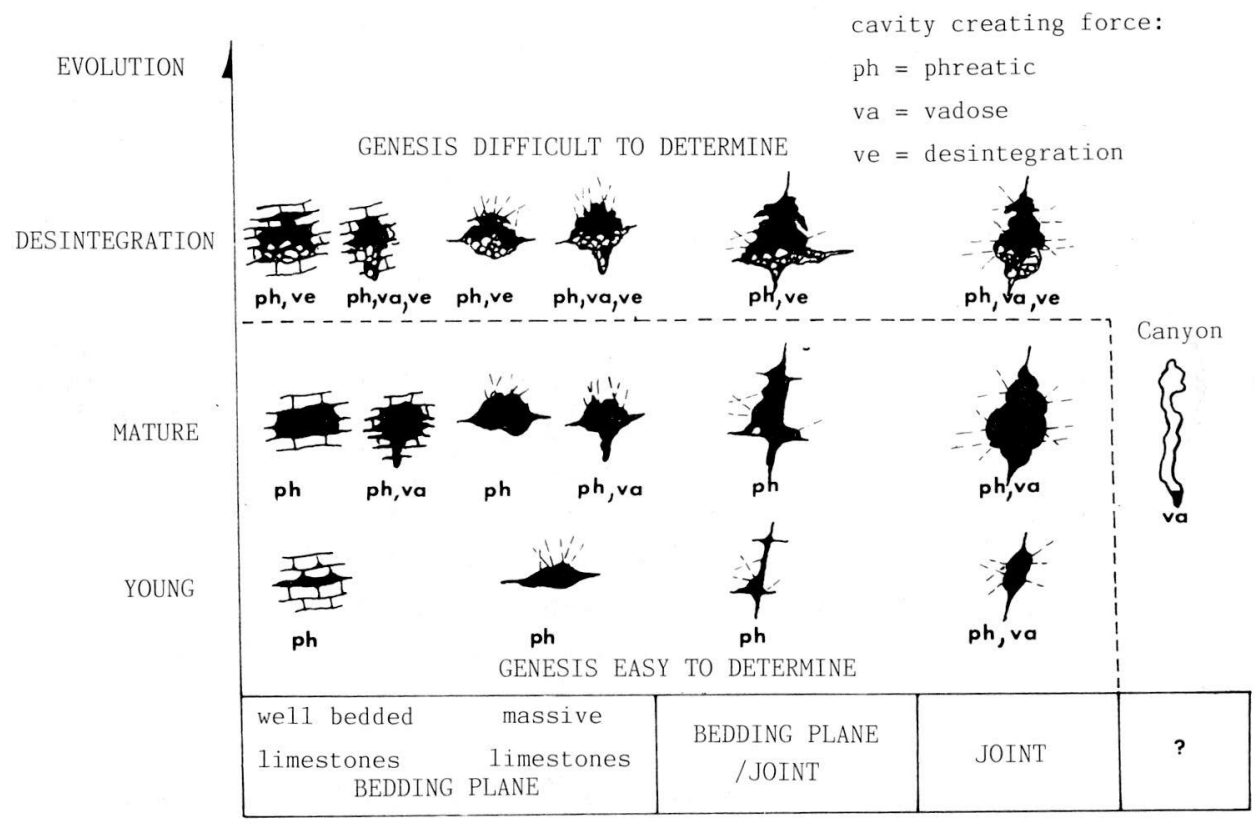

DOMINANT PLANE

Fig. 1: Appearance of tectonic and sedimentary planes in cavity-crosscuts. 
Special significance has to be put to the mixing corrosion which appears at intersections of planes keeping different acidulated waters; thereby agressive $\mathrm{CO}_{2}$ is nascent and enables again solution of carbonates (HÖLTING, 1980, see fig. 2).

Mixing corrosion is the most important fundamental to explain the relation-ship of passage traces and tectonic elements.

\subsubsection{VADOSE STAGE}

Vadose conditions appear if the water table declines leaving initial cavities. Processes at this stage are characterized by normal corrosion and erosion of subsurface flows. Sintering is another important phenomenon.

TRIMMEL (1968) demonstrated, that the intensity of sinter deposits is increased within highly jointed zones; this fact, again, can be used for tectonic investigations.

\subsubsection{COLLAPSE}

This desintegration stage characterizes a final step in the development of cave systems (BÖGLI, 1978). Of course, the suitability of those areas for the task in mind is decreased.

Fig. 1 summarizes the appearance of sedimentary and tectonic planes in cavity crosscuts with respect to the evolution stage.
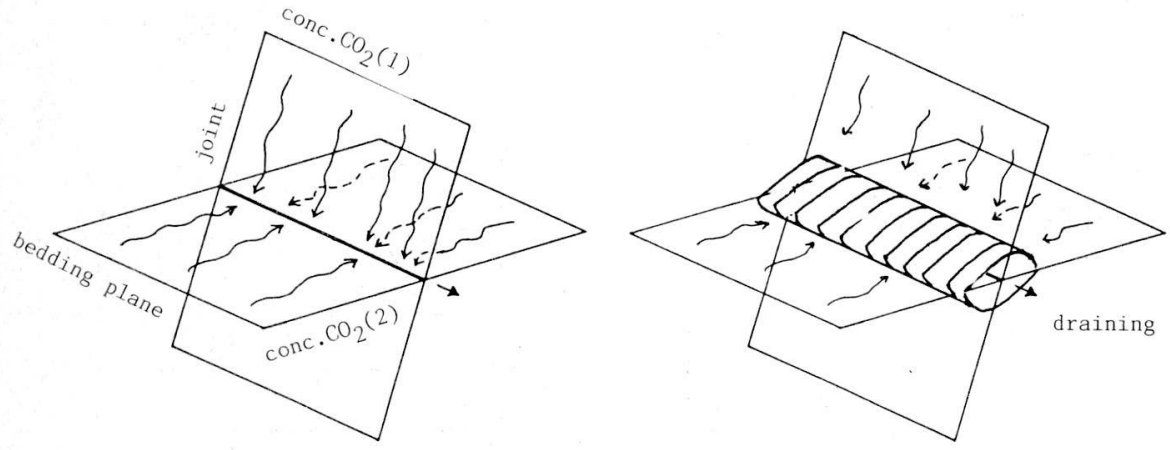

Fig. 2: Development of elliptical shaped passages due to mixing-corrosion at intersections of joint (conc. $\left.\mathrm{CO}_{2}(1)\right)$ and bedding plane (conc. $\mathrm{CO}_{2}(2)$ ). 


\subsubsection{THE GENESIS OF PASSAGES - BASIC CONSIDERATIONS}

As it was sketched before, most of the caves are originated and controlled by tectonics. Concerning the network caverns, however, a genesis by bedding planes was supposed without any influence of tectonic planes (BÖGLI, 1978).

But considering typical cross sections (e.g. Breathing Cave and Hölloch, see fig. 18 and 19) and cavity crosscuts (BÖGLI, 1978, p. 280, plate 3 ), a crucial influence of tectonic elements can be postulated. A strongly marked orthogonal pattern, elliptic crosscuts and very long plane passages underline this supposition. A considerable influence has the already mentioned mixing corrosion (fig. 2).

By this model, also the genesis of large caves can be explained taking into account the fact, that faults and lineaments mostly represent broad zones with intensely deformed and jointed rock complexes (JASKOLLA, 1978). Schematically, this is demonstrated by fig. 3. The solution of the
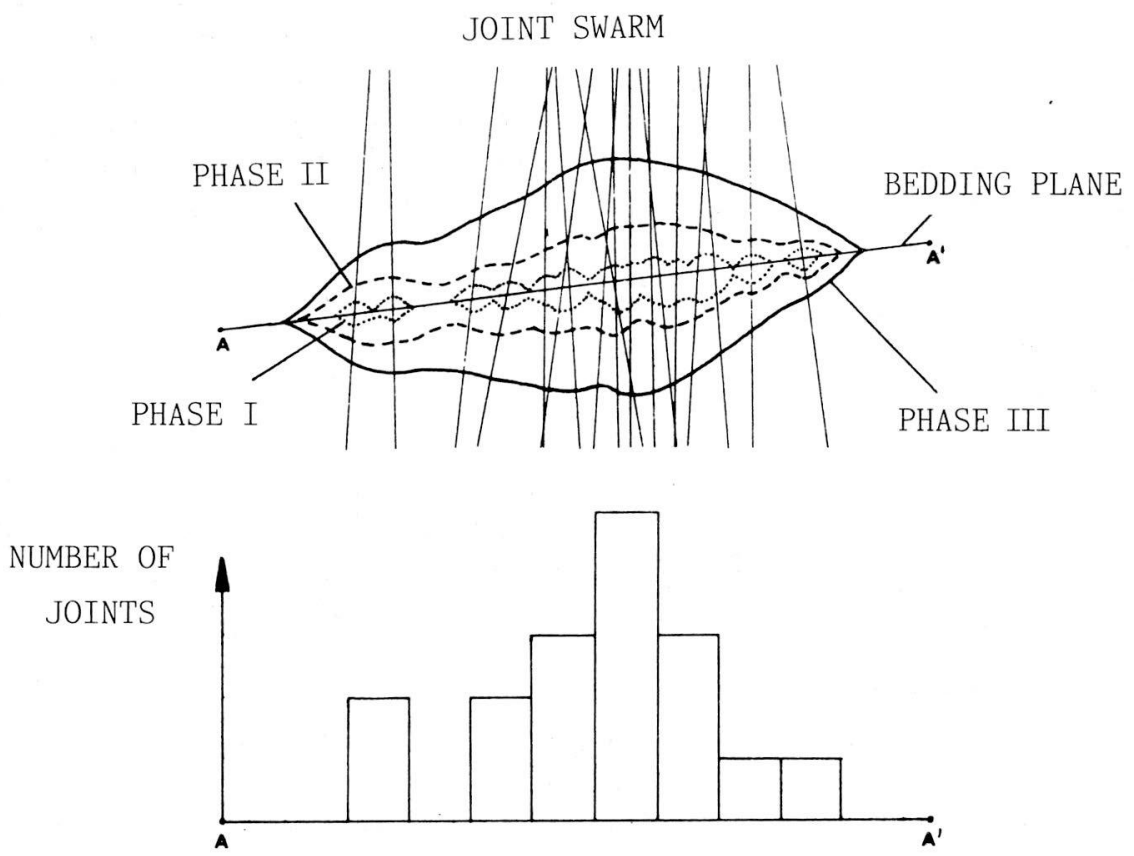

Fig. 3: Scheme for creation of big cavities due to mixing-corrosion. Main reason is the location at intersections of bedding plane(s) and joint- and fault swarms. 
carbonate starts within small, mostly linear zones (phase I) which leads summarizing, to large caves (phase III); characteristically they show turbolent walls with small slightly curved elements (BÖGLI, 1978). In this framework, joints must not be splitted open but can also represent planes able for capillary migration (BÖGLI, 1978, MURAWSKI, 1969).

The background of such a development concerning vadose corrosion was investigated mathematically by FRANKE (ref. TREIBS, 1962). Although he wanted to line out climatical influence and changes on the development of caves, his results support our model significantly.

By this extension on the genesis of caves results an additional basis for the correlation of passage traces and tectonic structures. Therefore, it is possible to use most passage traces as indicators for tectonical structures.

\subsection{SOME FUNDAMENTALS ON MICROTECTONICS}

In this presentation it is neither possible or necessary, to discuss in detail the fundamentals and problems of microtectonics.

Nevertheless some indispensable explanations for the understanding of the follovwing demonstration of examples have to be premised.

It was SANDER (1948) who defined the theorical basis by his cognition, geometric structure of a jointed rock reflects the physical forces acting on this body. Untill now, this fundamental consideration was verified deductively by manifold investigations (e.g. ADLER, 1970; SMOLKA 1977; JASKOLLA, 1976, 1978).

Summarizing the results, the following joint system can be distinguished specially when considering carbonate rocks:

o Orthogonal System (BOCK, 1980)

This type has to appear within all carbonate rocks because it is caused by diagenetic processes. Significantly two swarms of + orthogonal joints are existent, differentiated by their degree of regulation. If shear joints can be observed, they have to be explained by a superimposed stress (e.g. folding).

o B-oriented jointed system

If a horizontal compressive stress is acting on layered rocks, folds will be originated. With respect to the intensivity in time and space also typical joints will results. They show a distinct orientation towards the regional B axis. Besides "parting ruptures" shear joints are generated which enables a characterisation of folds. 
o Joint system related to faults

Mainly, there are three reasons responsable for such a joint system - the compressive stressacting on a rock is exceeding the mechanical boundaries of folding;

- the compressive stress is acting on non-layered, massive rocks;

- dilatation stress is acting on rocks.

Again "parting ruptures" and shear joints will be generated.

It is obvious, that these types may be superimposed on an intensively stressed area - a fact which can impede the association of joint systems significantly. Considering some criterions (e.g. statistical data collection and preparation, synoptic interpretation), however, these problems can be minimized.

\subsection{DATA COLLECTION AND PREPARATION}

To fullfill the task in mind, it was necessary, to select cave maps which realize the following requirements:

- sufficient accuracy of a survey must be guaranted;

- detailed crosscut and cross sections have to be available;

- the selected cave maps should represent areas with different tectonic evaluation.

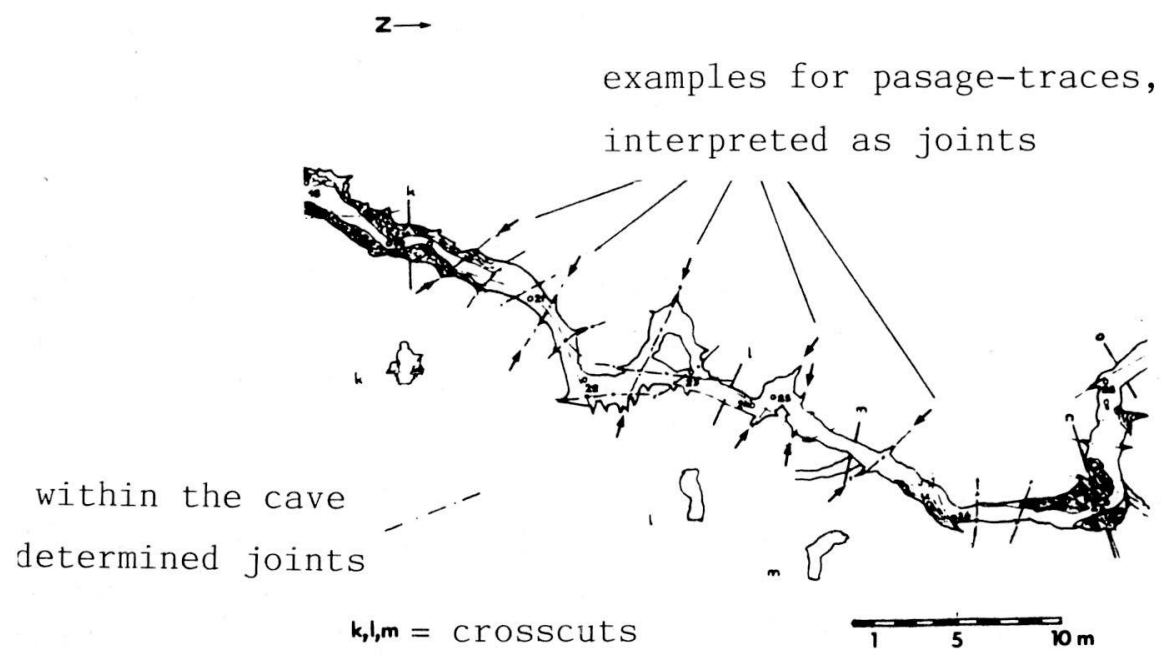

Fig. 4: Part of a cave plan (Binghöhle, fränk. Höhlenkataster C 15, Aufnahme H. Cramer, 1937, 1938) for demonstration of passage traces and joints. 
In the framework of our investigations the following experiences could be gathered which are fundamental for an efficient application of cave maps for tectonic investigations

- the association of passages and tectonics depends on the quality of survey and the description of cave systms; an increasing accuracy enlarges the applicability significantly;

- crossing traces of joints or fractures can be interpreted, if the cross section of passages shows salients on both sides of the walls (see fig. 4);

- a passage is indicated as a tectonic element by plane walls;

- isohpsal contours and their variations are important indicators of tectonic planes (fig. 5); secondary formations (sinter deposits, cave sediments, incasion) have to be considered;

- a separated evaluation due to the different zones in a cave (phreatic -phreatic-vadose - vadose) is necessary;

- the following parts of active maps are not usable: spiral passages (German: "Schneckengänge"), meandering canyons and broad regularly curved passages; due to isotropic large-scale jointing and vadose erosive processes, the tectonic origin is obliterated;

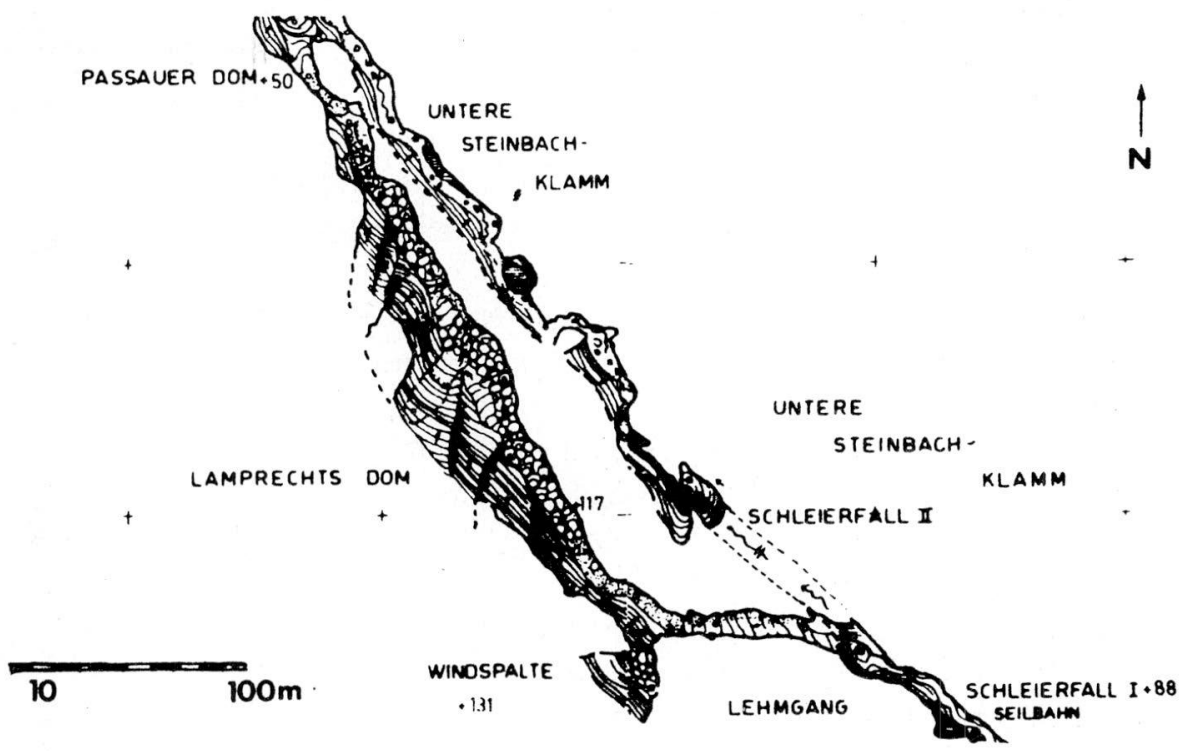

Fig. 5: Example for the importance of isohypsal contours in a cave plan (Lamprechtsofen, Kat. nt. 1324/1, Höhlenplan Bl. 4, Originalplan nach KLAPPACHER et al., 1976). Note: Lamprechtsdom $\left(\mathrm{h}_{\mathrm{rel}}+117 \mathrm{~m}\right.$ above entrance) and Steinbachklamm $\left(\mathrm{h}_{\mathrm{rel}}+88 \mathrm{~m}\right)$ are bound to one fault plane. Strike and dip can be taken approximately from the contour lines within the Lamprechtsdom. 
PERIPHERAL PARTS I TO VIII ARE USABLE

CENTRAL NOT USABLE ZONE; DUE TO DESINTEGRATION
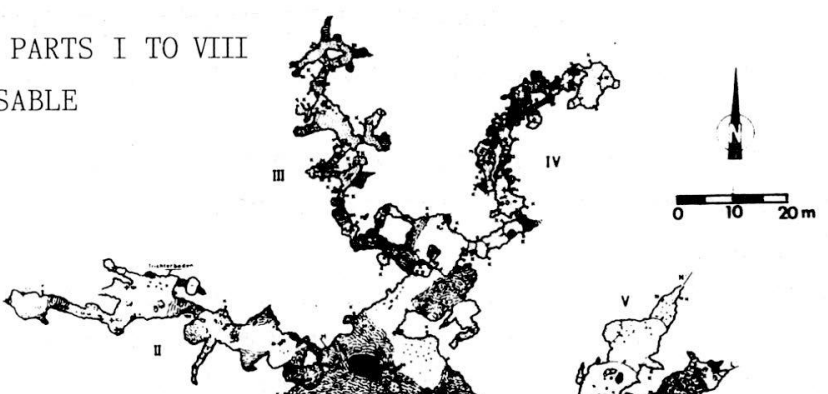


\section{THE APPLICABILITY OF CAVE MAPS FOR TECTONIC INVESTI- GATIONS - SOME SELECTED EXAMPLES}

With respect to the basic joint systems described in chapter 2.2., corresponding examples of existing cave maps were selected. Their location is indicated by fig. 7.

- Orthogonal system: Geisloch near Streitberg/NE Bavaria Schönstein - und Brunnsteinhöhle near Streitberg/NE Bavaria

- B-oriented system: Schlüsselloch near Chiemsee/S Bavaria Frickenhöhle near Garmisch-Partenkirchen/S Bavaria

- System rtlated to faults: Angerlloch near Walchensee/S Bavaria

- Complex system: Lamprechtsofen near Lofer/Austria Hölloch/\$witzerland.

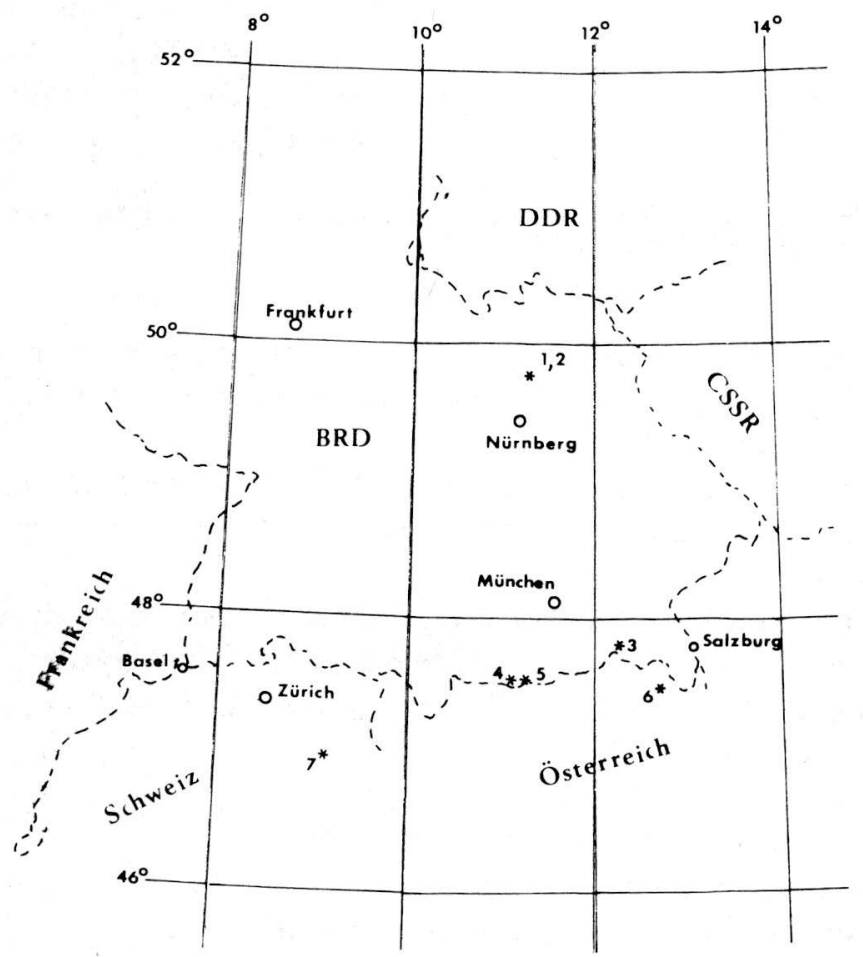

Fig. 7: Position of - caves, investigated in this paper $1=$ Geiloch, 2 = SchönsteinundBrentensteinhöhle, 3 = Schlüssellochhöhle, 4 = Frickenhöhle, 5 = Angerlloch, 6 = Larfprechtsofen, 7 = Hölloch 


\subsection{THE ORTHOGONAL SYSTEM}

With an area of about $6.400 \mathrm{~km}^{2}$, the "Fränkische Alb" represent the largest connected karst-surface of F.R.G. Flat-lying carbonate rocks of upper jurassic age offer ideal conditions for development of endo- and exo-karst. Intersected only by a few significant faults, the series are undisturbed. In addition, suitable results of detailed cave surveys are available. The occurence of the orthogonal system can be demonstrated excellent on most cave.

\subsubsection{THE GEISLOCH NEAR STREITBERG/NE BAVARIA}

The cave best surveyed in the "Fränkische Alb" is the Geisloch (Franconian cave cadester, No. c 58). It is running within nearly horizontal layered reef carbonates (dolomites) of tithonian age (Malm E, MAYER, 1972).

The existing cave map (DAUM in: SPÖCKER, 1980) was publisched in 1972 an shows up two nearly vertical passage system. The detailed evaluation of the passage traces and their statistical presentation confirm this first impression. Significant maxima of lineaments appear at $30^{\circ}$ and, with an evident dispersion, between $110^{\circ}$ and $150^{\circ}$ (fig. 8).

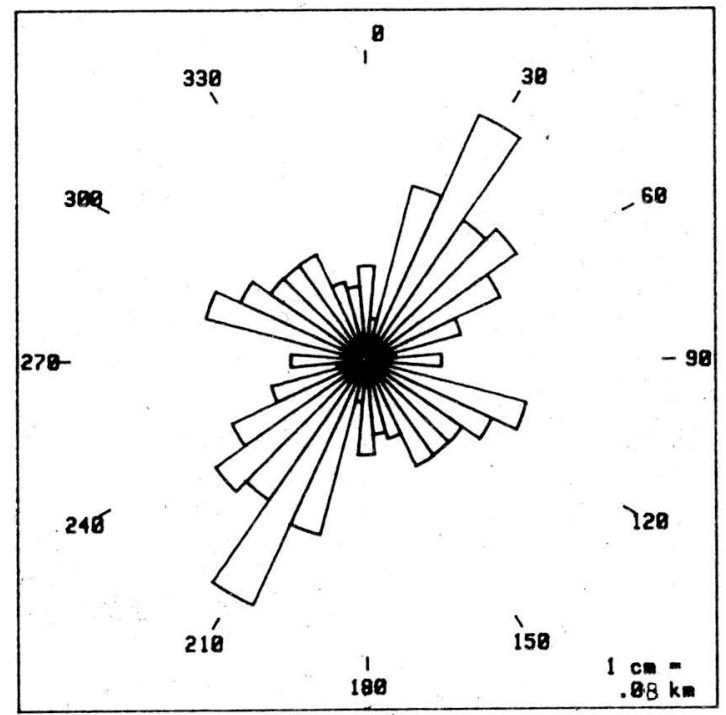

Fig. 8: Statistical distribution:

length of passage traces per striking sector in the Geisloch. 

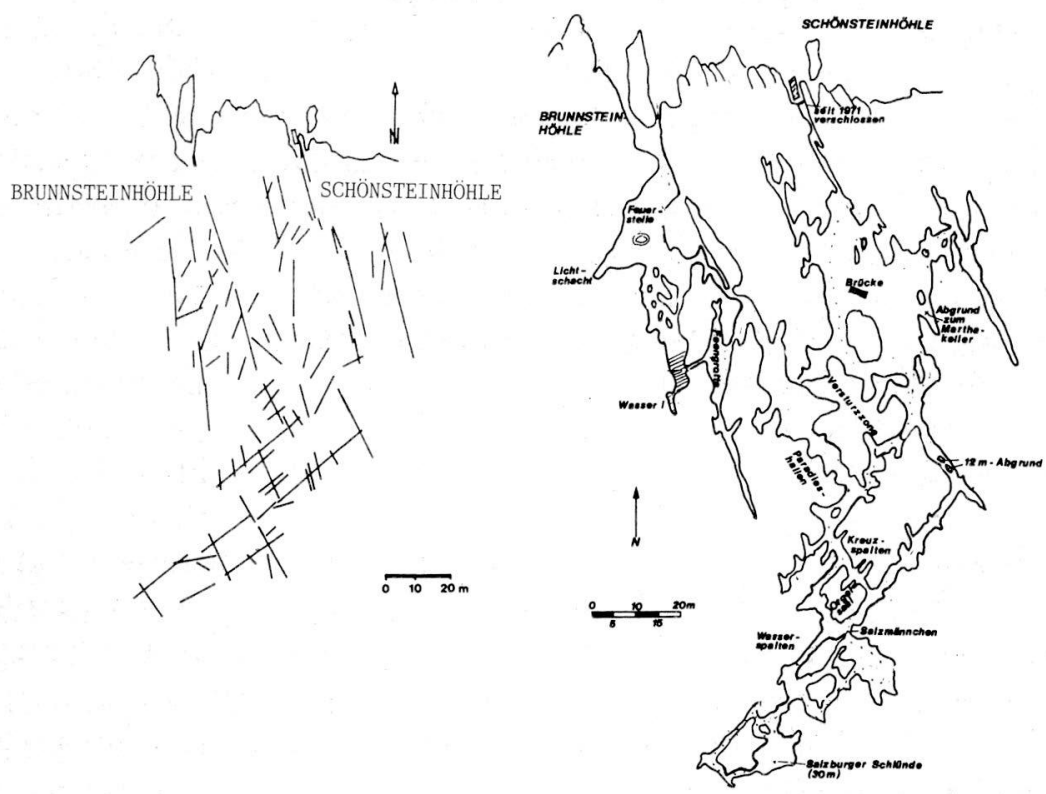

Fig. 9: Cave plan and mapped passage-traces from the Schönstein - and Brunnsteinhöhle (Fränk. Höhlenkataster c9/c10, Plan von THAMM, 1958).

Taking into account the fundamentals of microtectonics, an improved interpretation is enable. While former authors (KRUMBECK, 1956) connected joints in this area with the few, regional important faults, the application of an orthogonal joint system (BOCK, 1980) results in a more sophisticated interpretation. A primary joint set representing ${ }_{3}$ strikes at about $30^{\circ}$ is accompanied by a swarm of secondary joints representing ${ }_{1}$. This swarm is characterized by a high dispersion and relatively short striking lenghts due to the origin by stress inversion.

\subsubsection{SCHÖNSTEIN - UND BRUNNENSTEINHÖHLE NEAR STREITBERG/NE BAVARIA}

A few kilometers from the Geisloch, on the slopes of the Wiesent Valley, different cave system are located. They are described as "caves of the lower level", which indicate as well the location of the mouth as the stratigraphic position within Malm B carbonates. For the demonstration of the suitability for tectonical analysis, the Schönstein - und Brunnsteinhöle was selected (fig. 9). Obviously cave map and interpreted lineaments (as 
traces of joints) offer anc orthogonal passage pattern, which coincides suprisingly with the results obtained and described by BOCK (1980).

This preliminary interpretation has to be relatived by use of statistical distribition of the number of evaluated lineaments (fig. 10). Two aspects have to be discussed comparing the results of the interpretation of the Geisloch:

- the differences of the orientation of the maxima and

- the angle of about $70^{\circ}$ between the two maxima.

Concerning the last, rheological parameters of the thin-stratified carbonates may be responsable, expressing increased incompetent behaviour. The deviation of the strike direction, however, reflects differences in the stratigraphic development. MEYER $(1972,1974)$ proves, that due to facies differentation an orientation of the dolomit reefs of Malm B of approx. $170^{\circ}$ has to be suspected. The interpretation of this situation enables a correlation of the principle stress component 1 parallel to this stratigraphic boundary. Schematically, this reflection is demonstrated by fig. 11 .

Interpreting the rose diagram of fig. 10 in this sense, again a typical orthogonal joint system is obvious.

Beginning with Malm B (MEYER, 1974) a facies boundary near Streitberg can be observed, which follows a direction of about $30^{\circ}$ and is

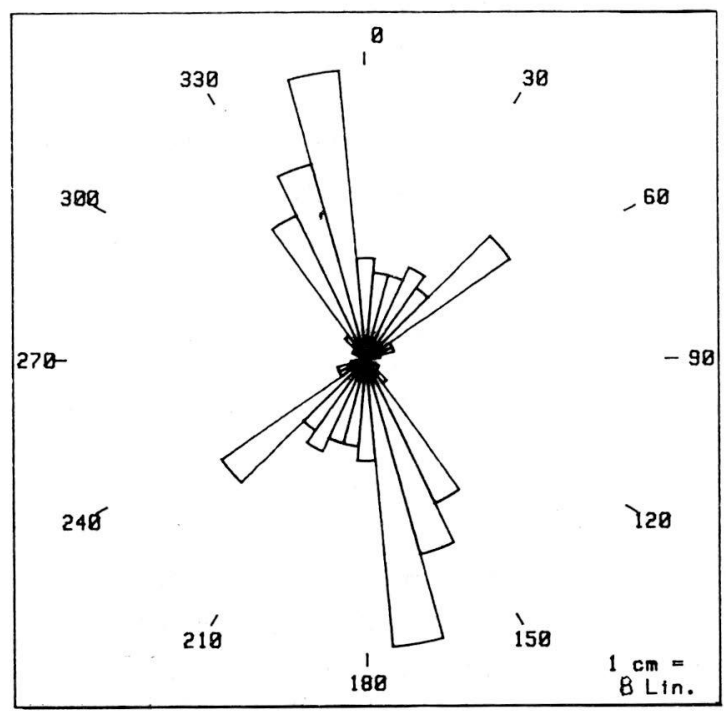

Fig. 10: Number of passage traces per striking sector from the Schönstein - and Brunnsteinhöhle. 


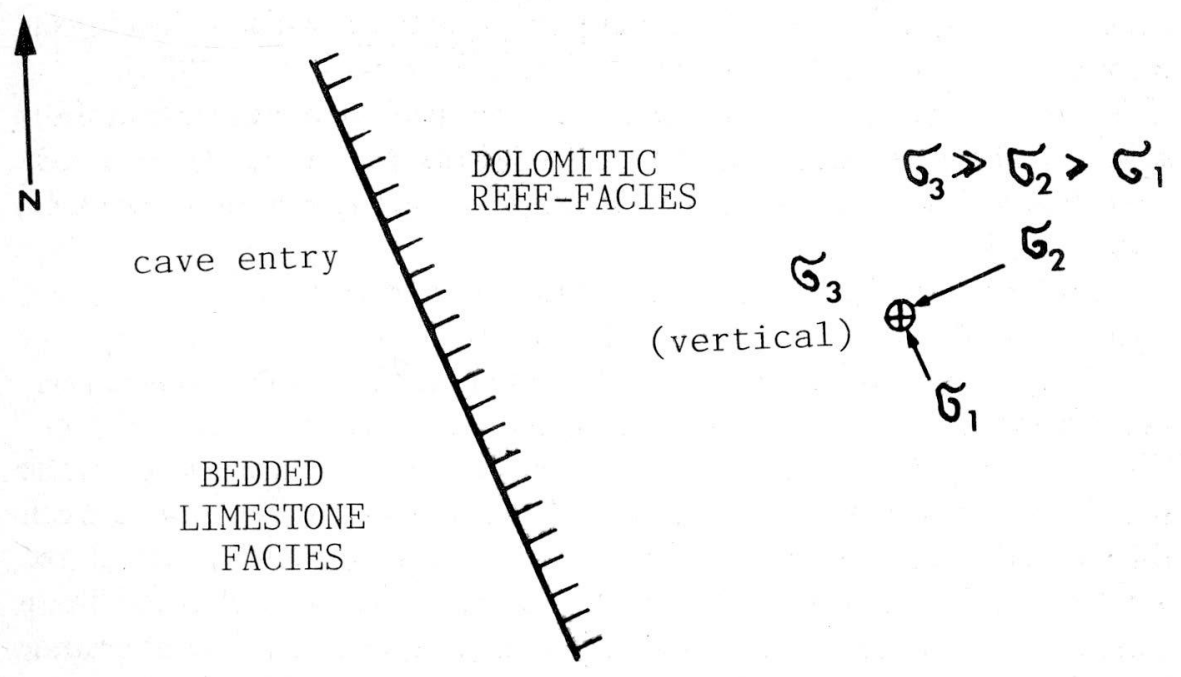

Fig. 11: Scheme of Facies boundary near lớcation of Schönstein - and Brunnsteinhöhle, malmß, upper jurassic.

active until early cretaceous. Again an orientation of the principle stress component 1 parallel to this direction can be suspected - a fact already proven by the results of the interpretation of the data the Geisloch (fig. 8).

The evaluation of the "Fränkische Alb" data finally have elaborated two aspects:

- cave maps, respectively the traces of passăge are suitable to describe the orientation of the orthogonal joint system;

- deviations can be explained, taking into account additional results of detailed geological investigations.

\subsection{B-ORIENTED JOINT SYSTEM}

\subsubsection{SCHLÜSSELLOCH}

The mouth of the cave system "Schlüsselloch" opens 1.274 m mean sealevel in the heavily karsted peneplain of the Laubenstein-Riesenberg area near Aschau/Chiemgau. Surveyes have outlined $1.400 \mathrm{~m}$ of passages with a depth of $150 \mathrm{~m}$ and a horizontale extend over $220 \mathrm{~m}$, completely within the well corrosionable Dogger limestone. This reddish formation 
build up by numerous crinoids, is heavily bedded and shows enormous residua of undilateable clays.

The Laubenstein area is part of the so called Northern Synclinorium within the Lechtal-nappe (TOLLMANN, 1976). Triassic and jurassic sediments of different lithology have undergone a severe folding. Single folds are often displayed by B-parallel thrust faults and sinistral strike slip faults (FISCHER, 1962, LANGE, 1962; VOLK, 1982). The cave's entrance is placed in the northern limb of a subordinate syncline of the synclinorium and its most distant parts run perpendicular to B into the hypothetical syncline core.

All passages show fracture bound origin and this allows a separation of the cave map's structures into two different zones (CRAMER \& TRILLER in TREIBS, 1962). Basing on detailed tectonic surveys, VOLK (1982) stated a specific superposition of folding phases for the main cave body, but a more regular pattern of surface near passages (phreatic created survey area west, fig. 12a). In this case, statistically unsignificant distributions are caused by a superposition of orthogonal and B-oriented fracture patterns. In opposite, the most distant cavities show preferred directions, partly due to selective erosion $\left(130^{\circ}\right)$ and younger, big fault planes $\left(170^{\circ}\right)$, (fig. $12 \mathrm{~b}$ ). Specially their intersections were important for development of voluminous cavities, which are clearly bound to tectonically deranged rock. It seems that strong folding didn't create many new joints and associate faults. Tectonic movements during a main phase of folding reactivated mostly the older, orthogonal system and subsequently rotated "tectonic blocks" within the carbonate body.

\subsubsection{FRICKENHÖLE}

The source "Kuhflucht" appears at 1.150 m mean sealevel near the western descent of the Estergebirge to the Loisach Valley. It drains nearly the entire alpine karst plain stretching eastwards to the small lake Wildsee. Only $100 \mathrm{~m}$ higher, the mouth of the Frickenhöle is stituated at a steep slope. Cave length is more than $2.4 \mathrm{~km}$ with a vertical range of $57 \mathrm{~m}$. All passages in the distant parts are hydrological active and mainly the "Styx" tributes most of its water to the Kuhflucht. The cave system is developed in well bedded uppertriassic limestone (Plattenkalk) between a dolomitic (Hauptdolomit) and a more shaly carbonate layer (Kössener Schichten). They are arranged in a syncline, B-striking $60^{\circ}$ and dipping slowly to the SW (JASKOLLA, 1975). Different resistance to corrosion make the 
Plattenkalk-Hauptdolomit interface an acquiclud. All water penetrating from the surface is gathered and flows towards the hydrological niveau of the Loisach. Drainage is completely controlled by the syncline structure and the dipping axis (WROBEL, 1970).

Due to the geological and hydrologixal condtions cave genesis was heavily affected by intersections of the B-oriented fracture system and bedding planes. Erosion in the B-parallel drainage system widened the initial cavities and grew to the dominant factor in the cave's history. So, nearly all passages show a convincing vadose shape; phreatic forms are rare and limited to a few places near the entrance.

Additionally recent landslips have created some so called "Urhohlräume", initial cavities according to LEHMANN (1932). They are in a surface-near position and extended recently by vadose and corrosive forces.

Distributions of passage traces from the cave map identified clearly B and Loisach-fault-parallel fractures (fig. 13a). Number and length of mapped lineaments (fig. 13a and b) show two maxima in the $70^{\circ}$ and $30^{\circ}$ sector, pointing out the different importance of B- and Loisach parallel planes for cavity genesis. Minor accumulations are due to $\mathrm{B}$ associated shear joints, partly reactivated by the later Loisach faults. All significant tectonic directions obtainable in the field are discernible from this diagrams, demonstrating not only their qualitative distribution, but also nature in differentiation between long and short traces. An orthogonal joint pattern is not detecable; the selective and dominant featurs of erosion have superimposed them completely.

Summarizing, the cave map with its typical vadose erosive pattern is best suited to give an impression of young tectonic events but not to obtain sedimentary joint patterns.

\subsection{JOINT SYSTEMS RELATED TO FAULTS}

\subsubsection{ANGERLLOCH}

The "Angerlloch" is surveyed to only $600 \mathrm{~m}$ lenght at $40 \mathrm{~m}$ height in total and opens $2 \mathrm{~km} \mathrm{SSW}$ of the Walchensee in the western slope of the Obernach Valley. A map was constructed in 1971 by TRILLER \& VATER in DOBEN (1976, fig. 14). Situated at the eastern edge of the Estergebirge, this cave is a further witness of strong karst influence on Plattenkalk within the Bavarian Synclinorium. In opposite to Frickenhöhle it is domi- 
nated by fault-oriented passage patterns. Sinistral, NE-striking strike slip faults, so called "Kesselbergstörungen" easily mappable on the surface, are a major factor.

The cave map (fig. 14) shows up three main passage directions, all having typical joint - and fault-bound crosscuts. Most obvious are lineaments striking $30^{\circ}$, sometimes changing in $0^{\circ}$; they are connected by lineaments at $150^{\circ}$. Statistical evaluation (fig. 15) identifies Kesselberg parallel features as a major, fault originated fracture swarm in this area $\left(30^{\circ}\right.$ $40^{\circ}, 20 \%$ of all measurements). An absolute maximum $\left(0^{\circ}, 18 \%\right)$ seems to represent an assymetric hk0-cluster associated with the main faults and both together give a good example of a Loisach fault pattern (sinistral strike). At $150^{\circ}$ some passages are conjugated to the "Ammer" lineaments (dextral strike).

Also this diagrams integrate all regional important tectonical lineaments as joint- and fault clusters.

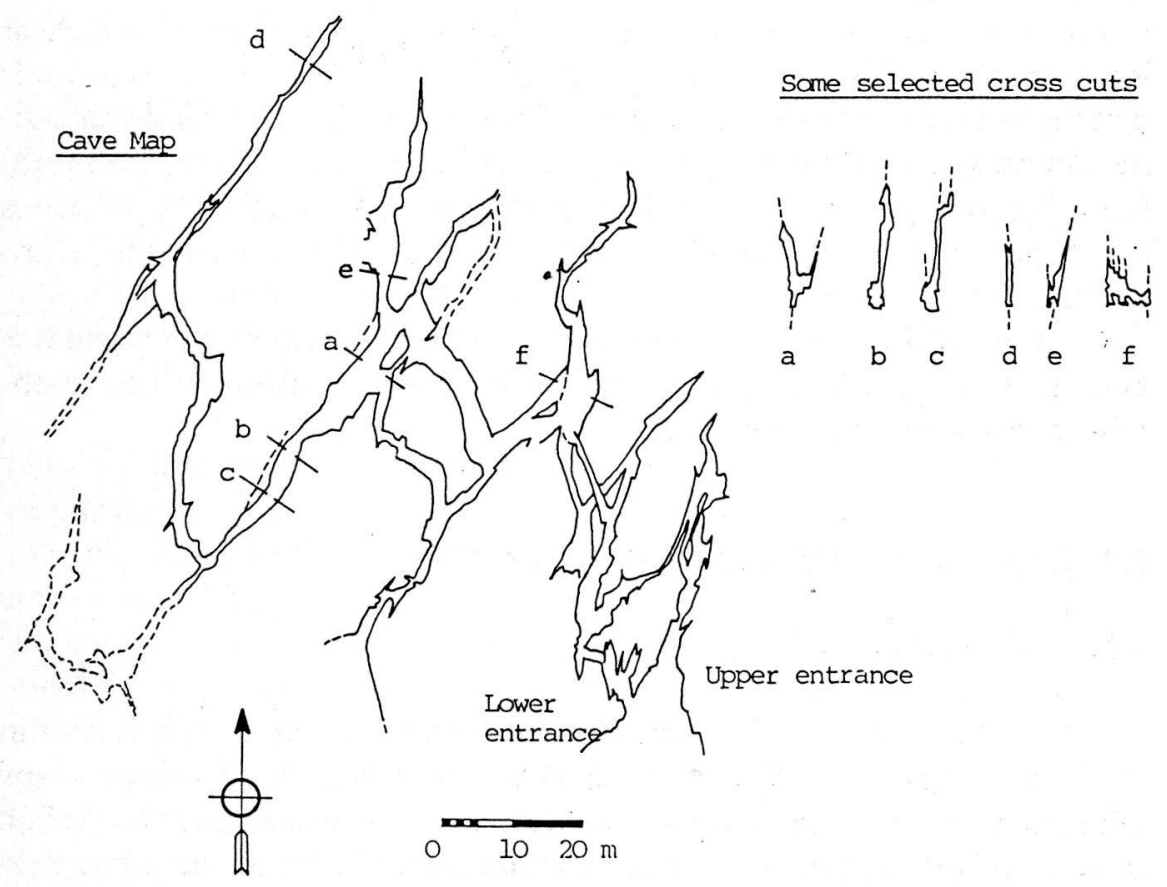

Fig. 14: Cave plan of Angerlloch (Kat. nr 1271/1, Verein f. Höhlenkunde München, Aufnahme TRILLER u. VATER, 1971). Typical pattern of a fault bound passage system. 


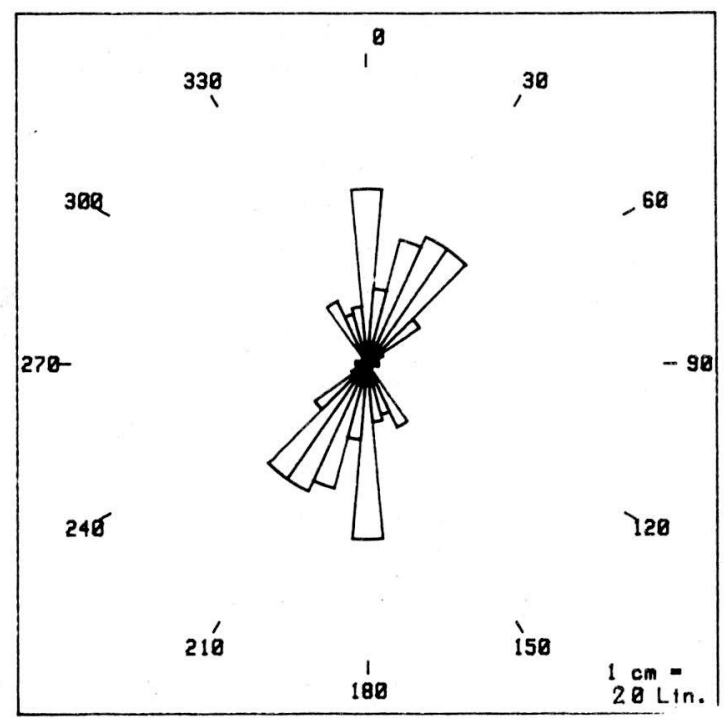

Fig. 15: Number of passage-traces per striking direction from the Angerlloch.

\subsection{HUGE CAVE SYSTEMS OF COMPLEX GENESIS (KOMPLEXE RIESENHÖHLEN)}

\subsubsection{LAMPRECHTSOFEN}

All recently investigated parts of the Lamprechtsofen (LAO) and other hydrological connected caves as Wieserloch, Rothöhle, Riesenkogelschlacht are developed in the northern roof of the Leoganger Steinberge (Salzburger Land, Austria).

Nearly the entire surrounding mountains are subterraneously drained by a network of canyons and piezometric tubes, sometimes appearing in the LAO. Thick uppertriassic carbonate sequence (Dachsteinkalk and -dolomit) build up a deeply corroded karstic terrain. Near the cave system they are arranged in a N-dipping anticline. Huge N-S- striking and steeply dipping fault planes displace the stratigraphical boundary dolomite/limestone. KLAPPACHER \& KNAPZYK (1977) found other tectonic important directions: NW-SE, NE-SW, E-W. As much as $90 \%$ of passages and cavities are judged as bound to fractures, expressing the absence of bedding planes within the massive carbonates.

Basis of the research was a map of KLAPPACHER \& KNAPZYK (1977). Summed up to more than $12.7 \mathrm{~km}$ length, LAO represents a type 
of alpine caves, characterized best as huge cave systems of complexe origin. From this follows, to be cautious in the discussion of their tectonics (ref. 2.3 ). In terms of statistics a separation is possible into two genetical groups by field observations:

- old and inactive upper levels, mostly phreatic, extending in several floors above the recently active hydrological niveau;

- relatively young vadose-phreatic and vadose-erosive parts, influenced by the recent karst water level.

Despite of some restrictions (ref. 2.3.), all vadose-erosive overprinted parts of this system were included in the investigations, because detailed additional field information from KLAPPACHER \& KNAPZYK (1977) and own research was available. Two different patterns are to discriminate. Phreatic upper levels are characterized by a typical orthogonal joint system $\left(50^{\circ} / 140^{\circ}\right.$, fig. 16$)$. In the length/sector diagram additional faults are to recognize at $160^{\circ}$. The recently active lower floors (fig. 17) don't show a orthogonal pattern, but the dominance of the youngest, $10^{\circ}$ striking faults.

Thanks to tectonic surveys in some northerly situated and similar structured carbonate masses (BODECHTEL et al., 1982a; BODECHTEL et al., 1982b; VOLK, 1982) the N-S linears can be identified as very young normal faults of an alpine dilatation phase. This is conform to fresh polished surfaces observed on the central fault in the cave. Maxima at $150^{\circ}$ $160^{\circ}$ obviously are used as drainage tunnels and perhaps over-represented. They outline the shortest passages for penetrating water from the anticlinal's centre to the hydrological base, approximately parallel to B.

\subsubsection{HÖLLOCH}

Inside the helvetian nappes of the "Schwyzer Kalkalpen" (Vierwaldstättersee/Switzerland) spread one of the most dendritic and best investigated cave systems. About $110 \mathrm{~km}$ length (1971) and total height of $740 \mathrm{~m}$ make an integrating consideration of all tectonic phenomena problematic.

It develops in the heavily karsted cretaceous limestone of the "Axendecke". The cave vertically cross "Drusbergschichten" at the bottom, "Schrattenkalk" and at its roof enters the "Seewerkalk". Some passages to upper levels even cut a minor nappe of the Axendecke.

Here, BÖGLI started basic research about speleological processes and their karst-hydrological meaning. He also published a detailed monogra- 


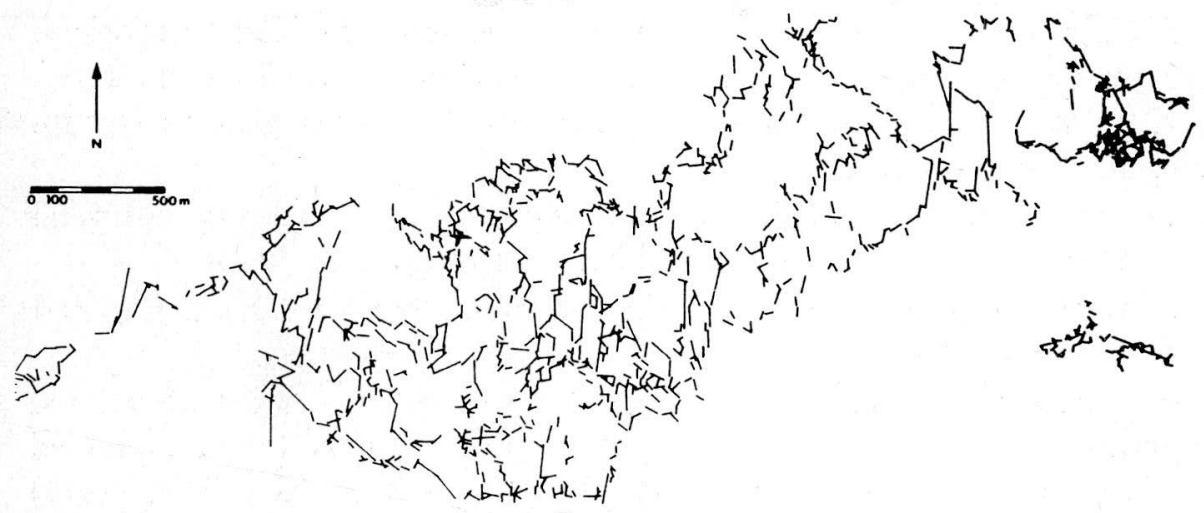

Fig. 18: Passage-traces of the active lower levels, Hölloch.

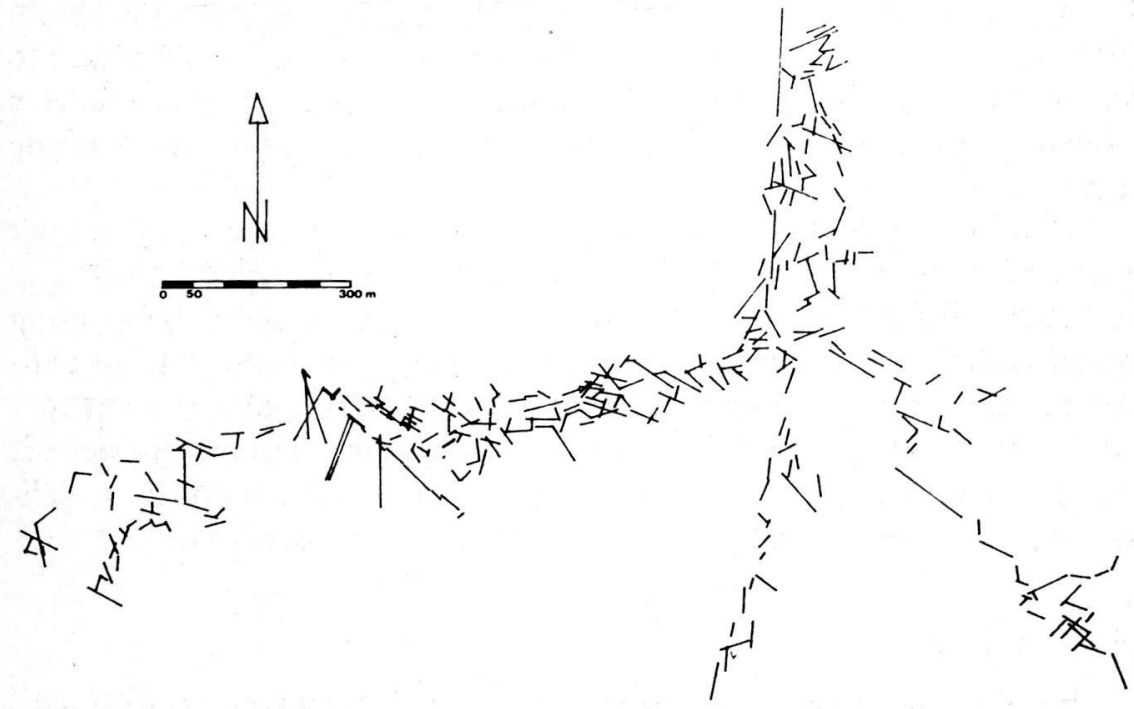

Fig. 19: Passage-traces of the ancient, inactive upper system, Hölloch.

phy of the Hölloch (1971).

The tectonic framework is outlined and N-S striking faults are delineated. He found a different structure of upper and lower levels: an hydrological jointbound upper floors, phreatic and inactive (fig. 19).

Similar to LAO, statistics of passage traces from upper levels implicate the phreatic origin due to the primary, orthogonal joint pattern (fig. 28). $80^{\circ}$ appart, two cluster stand for the genetically oldest planes. The length/sector diagram intensifies an absolute $0^{\circ}$-maximum meaning a 

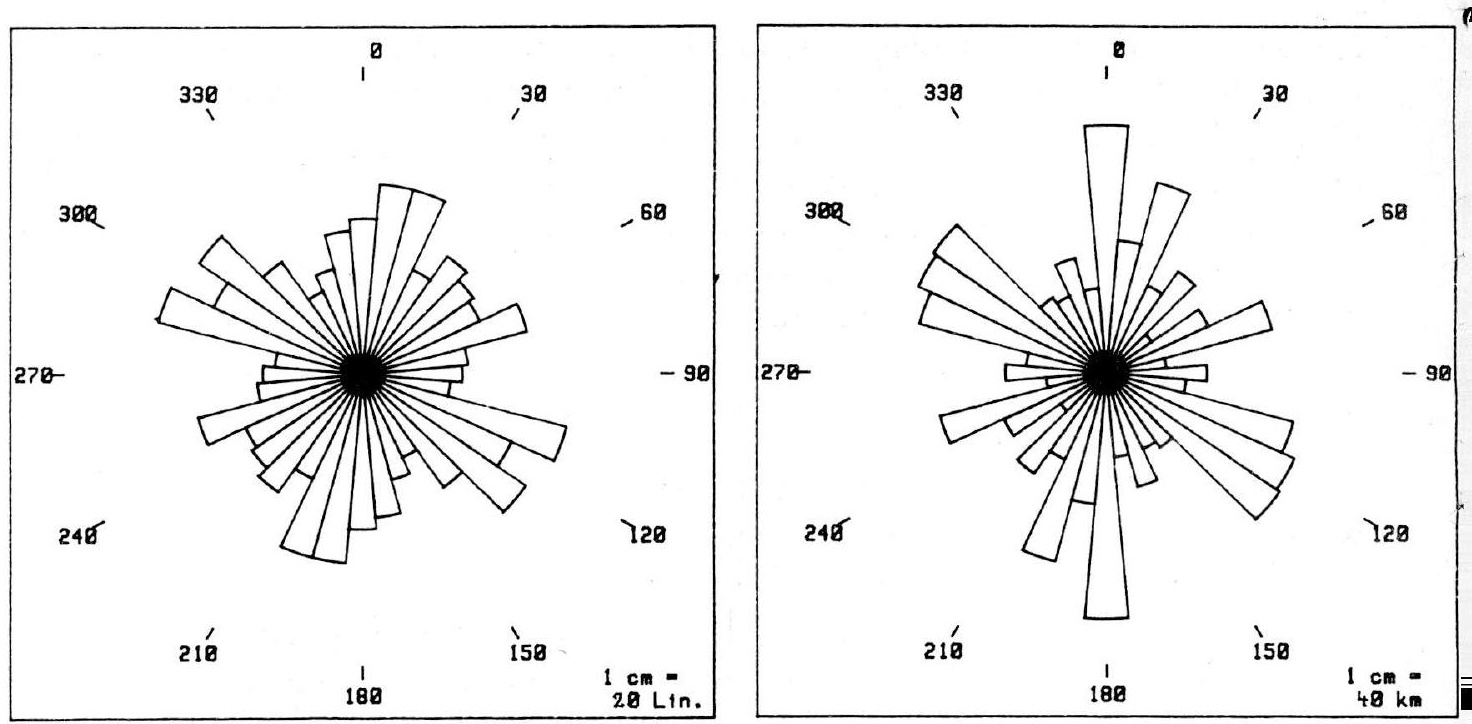

Fig. 20: Passage-traces per striking direction from the ancient, inactive upper levels of the Hölloch.
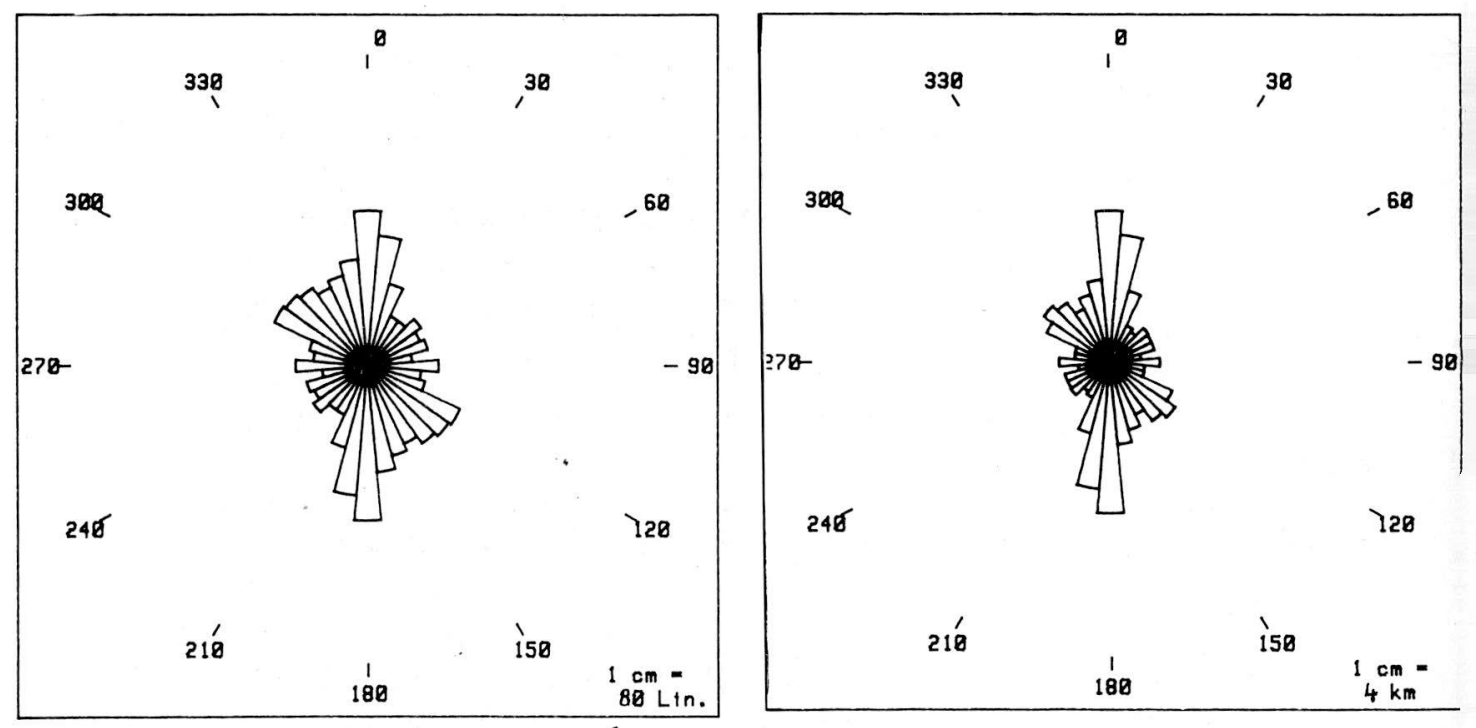

Fig. 21: Passage-traces per striking direction from the active lower levels of the Hölloch. 
few but extended faults. Passages in lower floors show an extremely developed $0^{\circ}$-direction, representing a good correlation with BÖGLI's results. Undoubtless they are mostly vertical, big-scale faults with unknown tension parameters. All other directions are of minor importance.

The last two examples demonstrate the ability of cave maps even from huge and complexe systems, to be used for tectonic surveys, if thematic processed before a statistical treatment.

\section{CONCLUSION}

Our presentation intends to demonstrate the suitability of cave maps to support tectonic investigations.

Fundamental requirements for this were:

- the availibility of detailled and accurate cave maps; fortunately, this is guaranteed by the important acitivities of many "hobby speleologists" within large areas;

- the solution of many speleological problems by BÖGLI and TRIMMEL;

- increased understanding of the fundamentals of microtectonics and their enlarged applicability;

- improved possibilities of statistical data processing and presentation;

- last not least, the extension on the genesis of caves as it is proposed within this presentation, is of upmost importance. It was possible to demonstrate that joint sets or fault zones are also responsible for the genesis of passages. Therefore, elliptical shaped passages like those of "network caverns" can be interpreted as bound to tectonic structures, too, though directelly no tectonic plane is evident.

Nevertheless, the interpretation of cave maps has to take into account the following aspects

- type of rock and stratification (e.g. dolomit - limestone, massive layered);

- the genesis of a cave and its current stage (phreatic - vadose - erosive) and

- secondary effects (e.g. sintering, incasion, cave deposits). 
Although single examples stress out the significant influence of superposition of speleo-morphologic and tectonic features, it can be stated, that existing cave maps can support the selection of relevant fabric patterns and therefore tectonical investigations as a whole. Additional aspects can be obtained in transferring this conclusions to other disciplines as scientific speleology and especially hydrogeology. Since water supply is a difficult item in karstic areas, preferred joint-water bodies might be detectable by application of some ideas stated.

\section{KURZFASSUNG}

Die Ergebnisse nachstehender Untersuchungen zeigen, daß die Informationen aus Höhlenplänen tektonische Erhebungen nutzbringend unterseẗzen können.

Unter Berücksichtigung des speleologischen Formenschatzes, der Höhlengenese und sedimentologischer und struktureller Besonderheiten ist die Ansprache von Trennflächensystemen aus der Verteilung von Gangspuren möglich. Anhand von 7 ausgewählten Plänen von Hölen in tektonischunterschiedlich geprägten Gebieten wird demonstriert, daß die drei Haupttypen von Kluftgefügen (Foundamentales, faltungs-und störungsgebundenes Gefüge) identifiziert werden können.

Es ist somit eine Aussageverbesserung tektonischer Modelle zu erwarten, weshalb die zusätzliche Verwendung von Höhlenplänen in ähnlichen Untersuchungen an anderen Objekten empfehlenswert ist.

\section{REFERENCE}

ADLER, R. E.: Störungsbezogene Gefügeprägung. - N. Jb. Geol. Paläent., Abh., S. 385413, Stuttgart, 1970.

Ein Beitrag zur angewandten Tektonik im Rubrkarbon. - Forsch. - Ber. Ld. Nordrh.-Westf., 2385, 135 S., 1973.

BAYER, H. J.: Brichtektonische Bestandsenifrualume in Bereich des Kenstenblattes 6626 Schrorbery Osl, 1:25000/Hohenlohe.- Oberheim Geol. Abb. N. 34, S. 29-42, Karlshihe, 1985.

Bock, H.: Das Fundamentale Kluftsystem. - Z. D. Geol. Ges., 50, S. 627-650, Hannover, 1980.

Bodechtel, J., Jaskolla, F., Kohlhammer, G.: Geologie und Tektonik des Gebietes zwischen Funtensee und Schwarzensee/Steinernes Meer. - $110 \mathrm{~S}$., Forsch. - Ber. d. Alpennationalparks Berchtesgaden, Berchtesgaden, 1982 a. 
BODECHTEL, J., JASKOLLA, F., TOMSCHI, H.P.: Geologische Kartierung im Rointgebiet zwischen Königssee und Watzmann. - 135 S., Forsch. - Ber. d. Alpennationalparks Berchtesgaden, Berchtesgaden, 1982 b.

BöGLI, A.: Das Hölloch und sein Karst. - Sonderveröffentlichung des "Stalactite", 109 S., Neuchâtl, 1971.

- : Karsthydrographie und physische Speleologie.- 310 S., Springer Verlag, Berlin, Heidelberg, New York, 1978.

Cramer, K. \& Triller, A.: Die Höblen im Laubenstein und seiner Umgebung. - in TreiBs, W.: Das Laubensteingebiet im Chiemgau. - 3. Jahresheft des Verb. d. Deutsch. Höhlen - und Karstforscher, 338 S., S. 69 - 125, München, 1962.

Doben, K. (HRSG): Geol. Karte von Bayern, 1:25000, Erlauterungen zu Blatt Nr. 8433, Eschenlohe.- Bayer. Geol. Landesamt, 96 S., 19 Abb., 4 Tab., 7 Beil., München, 1976.

FISCHER, H.: Geologisch-paläntologische Untersuchungen im Gebiet Hochries - Spielberg (Chiemgauer Alpen). - 50 S., Unveröffentl. Dipl.- Arb. d. Univ. München, München, 1962.

Franke, H. W.: Formgesetze der Korosion. - in TreIBS, W.: Das Laubensteingebiet im Chiemgau. - 3. Jahresheft des Verb. d. Deutsch. Höhlen und Karstforscher, 338 S., 207-225, München, 1962.

HENKEL, J: Usage for a Desktop Computer System for Geo-Photogrammetric Interpretation of Image Data.- IEEE Int. Geoscience \& Remote Sensing Symp., Munich, 1982.

Hölting, B.: Hydrogeologie. - 340 S., 103 Abb., Enke Verlag, Stuttgart, 1980.

JASKolla, F.: Geologische Neuaufnahme des Krottenkopfgebietes. - 89 S., Unveröffentl. Dipl.-Arb. d. Univ. München, München, 1975.

- : Zur Tektonik der Krottenkopfgruppe.- in DoBen, K.: Geol. Karte von Bayern, 1:25000, Erläuterungen zu Blatt Nr. 8433, Eschenlohe. - Bayer. Geol. Landesamt, 96 S., 19 Abb., 4 Tab., 7 Beil,. München, 1976.

- $\quad$ Geologisch-tektonische Untersuchungen an Satellitenbildlineamenten in den Nördlichen Kalkalpen. - 118 S., 35 Abb., 2 Tab., Diss. Univ. München, München, 1978.

KLAPPACHER, W. \& KNAPCZYK, H. (HRSG): Salzburger Höhlenbuch Band 2. - 348 S., 197 Abb., Landesverein für Höhlenkunde in Salzburg, Salzburg, 1977.

KrumbeCK, L. (HRSG): Geol. Karte von Bayern, 1:25000, Erläuterungen zu Blatt Nr. 6232 Forchheim. - Bayer. Geol. Landesamt, 80 S., 2 Abb., 4 Taf., München, 1956.

LANGE, S. D.: Zur Stratigraphie und Paläontologie im Laubensteingebiet in den Chiemgauer Alpen. - 56 S., Unveröffentl. Dipl.-Arb. d. Univ. München, München, 1962.

Lehmann, O: Die Hydrographie des Kartes. - Franz Deutike Verlag, Wien, 1932.

MEYER, R.: Stratigraphie und Fazies des Frankendolomits (Malm) 1. Teil: Nördliche Frankenalb. - Erlanger geol. Abh., H. 91, 28 S., Erlagen, 1972.

- Stratigraphie und Fazies des Frankendolomits (Malm) 1. Teil: Mittlere Frankenalb. - Erlanger geol. Abh., H. 96, 34. S., Erlangen, 1974.

Murawski, H. (HRSG): Deutsches Handwörterbuch der Tektonik. - 2. Lieferung, Hannover, 1969. 
SANDER, B.: Einführung in die Gefügekunde geologischer Körper; 1 Teil: Allgemeine Gefügekunde und Arbeiten im Bereich Handstück bis Profil. - 215 S., WienInnsbruck, 1948.

SMOLKA, A.: Terrestrisch-Photogrammetrische und Satelliten-Aufnahmen als Grundlagen für tektonische Untersuchungen - dargestellt am Beispiel des Nördlichen Apennins. - 90 S., Diss. Univ. München, München, 1977.

SPÖCKER, R. G.: Forschungsergebnisse aus dem Geisloch bei Oberfellendorf und benachbarte Höhlen um Muggendorf und Streitberg (nördl. Frankenalb). - Karst un Höhle, Jg. 1980, 74 S., München, 1980.

Tollmann, A.: Der Bau der Nördlichen Kalalpen - Monographie der Nördlichen Kalkalpen, Bd. 3. - 499 S., Wien, 1976.

Trimmel, H.: Höblenkunde. - 300 S., 88 Abb., Viewing \& Sohn, Braun-??schweig, 1968.

VolK, P.: Diplomarbeit: Teil 1: Kartierung im Gebiet Watzmann - Bartholomä - Hachelköpfe in Alpennationalpark Berchtesgaden; Teil 2: Möglichkeiten zur Erweiterung tektonischer Modelle mit Daten aus Karsthöhlen am Beispiel der Schlüssellochhöhle im Laubenstein/Chiemgau. - 101 S., Unverröffentl. Dipl.-Arb. d. Univ. München, München, 1982.

Wrobel, J. P.: Hydrologische Untersuchungen im Einzugsgebiet der Loisach zwischen Garmisch-Partenkirchen und Eschenlohe. - Diss. Univ. München, München, 1970. 